\title{
ANALISIS TEGANGAN LANGKAH DAN TEGANGAN SENTUH SERTA PERENCANAAN SISTEM PEMBUMIAN PADA PEMBANGUNAN SUBSTATION VVIP DI BANDAR UDARA INTERNASIONAL I GUSTI NGURAH RAI BALI
}

\author{
Kadek Mirah Mahadewi ${ }^{1}$, I Gusti Ngurah Janardana ${ }^{2}$, I Wayan Arta Wijaya ${ }^{3}$ \\ ${ }^{1,2,3}$ Program Studi Teknik Elektro, Fakultas Teknik, Universitas Udayana \\ Email : mirahmahadewi398@gmail.com ${ }^{1}$, janardana@unud.ac.id ${ }^{2}$ \\ , artawijaya@ee.unud.ac.id ${ }^{3}$
}

\begin{abstract}
Abstrak
Bandar Udara Internasional I Gusti Ngurah Rai Bali sebelumnya memiliki Substation (SS) D berfungsi melayani sistem kelistrikan untuk pengoperasian pompa limbah dan airline, namun saat ini substation tersebut sedang dilakukan pengembangan dengan dibangunnya SS VVIP yang melayani sistem kelistrikan untuk pengoperasian gedung VVIP serta pompa limbah dan airline. Untuk menjaga keamanan peralatan dan manusia yang berada di sekitar gedung SS VVIP dibutuhkan sistem pembumian yang baik dengan nilai tahanan pembumian $<1 \mathrm{Ohm}$. Karena tanah di Bandara Ngurah Rai merupakan tanah berpasir, sistem pembumian yang cocok yaitu sistem pembumian Pelat, Mesh, Grid-Rod [1]. Untuk mendapatkan nilai $\mathrm{R}<1 \mathrm{Ohm}$, dibutuhkan sebuah analisis dari masing - masing sistem pembumian yaitu Pelat, Mesh, Grid-Rod.

Hasil analisis didapatkan bahwa sistem yang paling aman adalah sistem pembumian Grid-Rod dengan nilai tahanan pembumian $0,3718 \mathrm{Ohm}$, nilai tegangan sentuh 223,51 Volt, nilai tegangan langkah 1188,69 Volt dan biaya perencanaan Rp 7.712.500,-. Berdasarkan data perencanaan pembangunan SS VVIP Bandara Ngurah Rai sistem pembumian yang digunakan sama dengan hasil analisis yaitu sistem pembumian Grid - Rod.
\end{abstract}

Kata kunci : Substation, Sistem Pembumian, Tegangan Langkah, Tegangan Sentuh

\section{Abstract}

I Gusti Ngurah Rai International Airport Bali previously had a Substation (SS) D which serves the electrical system for the operation of modified Sewage Treatment Plant, however that substation currently under development with the construction of SS VVIP which serves the electrical system for the operation of VVIP buildings and Sewage Treatment Plant. To maintain the security of equipment and humans around the SS VVIP building a good grounding system is needed with a grounding resistance value of $<1 \mathrm{Ohm}$. Because the land at Ngurah Rai Airport is sandy land, the suitable grounding systems are Pelat, Mesh, Grid-Rod groundinh systems [1]. To get an R value $<1 \mathrm{Ohm}$, an analysis of each grounding system is needed, namely Pelat, Mesh, Grid-Rod.

The results of the analysis showed that the safest system was the Grid-Rod grounding system with a grounding resistance value of $0.3718 \mathrm{Ohm}$, a touch voltage value of 223.51 Volt, a step voltage value of 1188.69 Volt and a planning cost of Rp7,712,500. Based on the construction planning data of the SS VVIP Ngurah Rai Airport, the grounding system used is the same as the result of the analysis of the Grid - Rod grounding system.

Keywords: Substation, Grounding System, Step voltage, Touch voltage

\section{PENDAHULUAN}

Bandara Internasional I Gusti Ngurah Rai Bali sedang mengembangkan paket pekerjaan Konstruksi Apron Timur dan Pemindahan Sewage Treatment Plant (STP). Dengan adanya pekerjaan ini, maka dibangun SS VVIP dengan suplai listrik utama bersumber dari Main Power House (MPH) 1 Tegangan Menengah $20 \mathrm{kV}$.
Lokasi Bandar Udara Internasional I Gusti Ngurah Rai berada di pinggir pantai dengan tanah berpasir yang memiliki tahanan jenis tanah ( $\rho$ tanah) cukup tinggi akan mempengaruhi besarnya gradien tegangan pada permukaan tanah yang akan menyebabkan tegangan sentuh dan tegangan langkah yang melewati batas aman bagi manusia [2]. Sehingga 
membutuhkan jenis sistem pembumian yang tepat dengan nilai tahanan pembumian mendekati nilai nol atau $<1$ Ohm [3]. Sistem pembumian akan mengalirkan arus gangguan ke tanah dengan menciptakan jalur resistansi pembumian dengan cara penanaman elektroda pembumian.

Berdasarkan hal tersebut, maka dalam penelitian ini membahas tentang Analisis Tegangan Langkah dan Tegangan Sentuh serta Perencanaan Sistem Pembumian pada Pembangunan Substation VVIP di Bandar Udara Internasional I Gusti Ngurah Rai Bali.

\section{SISTEM PEMBUMIAN}

\subsection{Definisi}

Sistem pembumian merupakan suatu metode pengamanan gedung beserta peralatan apabila terjadi arus lebih akan dialirkan ke tanah melalui elektroda pembumian sehingga dapat mengamankan komponen-komponen peralatan dan manusia dari gangguan baik itu gangguan surja petir dan hubung singkat. Sistem pembumian yang ideal dengan nilai tahanan pembumian mendekati nol atau < 1 Ohm [3][4].

\subsection{Jenis - jenis Sistem \\ Pembumian}

\subsubsection{Elektroda Pita}

Elektroda yang ditanam secara dangkal dan mendatar (horizontal) di dalam tanah ini merupakan elektroda yang terbuat dari hantaran berbentuk pita atau berpenampang bulat atau hantaran pilin yang pada umumnya ditanam secara dangkal dan secara mendatar (horizontal) di dalam tanah [5].

$$
R_{p t}=\frac{\rho}{\pi L_{W}}\left[\ln \left(\frac{2 L_{W}}{\sqrt{d_{W} Z_{W}}}\right)+\frac{1,4 L_{W}}{\sqrt{A_{W}}}-5,6\right] \ldots
$$

\subsubsection{Elektroda Batang (Rod)}

Elektroda batang merupakan elektroda dari pipa atau besi baja yang dilapisi tembaga yang penanamannya ditancapkan ke dalam tanah secara tegak lurus atau mendatar [5].

$$
R=\frac{\rho}{2 \pi L}\left[\ln \left(\frac{4 L}{a}\right)-1\right]
$$

\subsubsection{Elektroda Pelat}

Elektroda pelat adalah elektroda dari bahan pelat logam (utuh atau berlubang) atau dari kawat kasa yang dipasang tegak lurus didalam tanah. Jika diperlukan beberapa pelat logam untuk memperoleh tahanan pembumian yang lebih rendah, maka jarak antara pelat logam jika dipasang paralel dianjurkan minimum 3 meter [5][6].

$$
R_{P l}=\frac{\rho}{4 \pi L}\left[1+1,84 \frac{b}{t}\right]
$$

\subsubsection{Sistem Pembumian Mesh}

Sistem pembumian Mesh merupakan sistem pembumian dengan konduktor yang ditanam secara sejajar (horizontal) yang terhubung satu sama lainnya sehingga berbentuk jaring-jaring yang ditanam sejajar pada permukaan tanah [7].

$R_{m}=\rho\left[\frac{1}{L_{c}}+\frac{1}{\sqrt{20 A}}\left(1+\frac{1}{1+h \sqrt{\frac{20}{A}}}\right)\right]$

\subsubsection{Sistem Pembumian Grid}

Pada sistem pembumian grid, batang-batang elektroda ditanam sejajar dibawah permukaan tanah, batang-batang ini terhubung satu dengan yang lain. Penggabungan sistem pembumian Mesh dan Rod sering disebut dengan sistem pembumian Grid [7].

$$
R_{G}=\frac{R_{1} R_{2}-R_{m}^{2}}{R_{1}+R_{2}-2 R_{m}}
$$

\subsection{Tegangan Sentuh}

Tegangan sentuh adalah tegangan yang terdapat diantara suatu objek yang disentuh dan suatu titik berjarak 1 meter pada permukaan tanah, dengan asumsi bahwa objek yang disentuh dihubungkan dengan sistem pembumian [7].

$$
E_{s 50}=\left[1000+1,5 C_{s} \cdot \rho_{s}\right] \frac{0,116}{\sqrt{t_{s}}}
$$

\subsection{Tegangan Langkah}

Tegangan langkah adalah tegangan yang timbul diantara kedua kaki manusia yang sedang berdiri diatas tanah yang sedang dialiri arus gangguan ketanah tanpa menyentuh peralatan [7].

$$
E_{l 50}=\left[1000+6 C_{s} \cdot \rho_{s}\right] \frac{0,116}{\sqrt{t_{s}}}
$$

\subsection{Tegangan Mesh}

Tegangan mesh merupakan salah satu bentuk tegangan sentuh, yang didefinisikan sebagai tegangan peralatan yang dibumikan terhadap titik tengah daerah yang dibentuk konduktor grid atau kisi-kisi (center of mesh) selama terjadinya gangguan tanah [8].

$$
E_{m}=\frac{\rho I_{G} K_{m} K_{i}}{L_{c}+L_{R}}
$$




\subsection{Tegangan Langkah Maksimum}

Tegangan langkah maksimum adalah perbedaan tegangan yang terdapat diantara kedua kaki manusia bila berjalan diatas permukaan sistem pembumian pada saat terjadi gangguan [8].

$$
E_{l m}=\frac{\rho I_{G} K_{S} K_{i}}{0,75 . L_{c}+0,85 . L_{R}}
$$

\section{METODE PENELITIAN}

Penelitian ini dilaksanakan di sekitar Bandar Udara Internasional I Gusti Ngurah Rai Bali yang dimulai dari bulan Oktober 2018. Alur analisis yang digunakan dalam penelitian ini adalah :

1. Mengumpulkan data tahanan tanah dan menghitung data tahanan jenis tanah di sekitar Substation VVIP di Bandar Udara Internasional I Gusti Ngurah Rai Bali sesuai dengan katalog alat ukur (Elohmi $\mathrm{Z}(42 / 35-86-2 \mathrm{XP}) \rho=2 \pi . a . R$.

2. Menghitung sistem pembumian Pelat.

3. Menghitung sistem pembumian Mesh.

4. Menghitung sistem pembumian GridRod.

5. Menghitung kriteria tegangan sentuh yang diizinkan.

6. Menghitung kriteria tegangan langkah yang diizinkan.

7. Menghitung tegangan Mesh (Mesh Voltage).

8. Menghitung tegangan langkah maksimum.

9. Menghitung (RAB) sistem pembumian.

\section{HASIL DAN PEMBAHASAN}

\subsection{Pengukuran Tahanan Tanah di} SS VVIP

Sebelum melakukan analisis dilakukan pengukuran tahanan tanah (R) untuk mendapatkan nilai tahanan jenis tanah $(\rho)$.

Tabel 1. Data Hasil Pengukuran Tahanan Tanah (R) dan Tahanan Jenis Tanah $(\rho)$

\begin{tabular}{|c|c|c|c|c|}
\hline $\begin{array}{c}\text { No } \\
\cdot\end{array}$ & Hari/Tanggal & $\begin{array}{c}\text { Pukul } \\
\text { (WITA) }\end{array}$ & $\begin{array}{c}\text { Tahanan } \\
\text { Tanah (R) }\end{array}$ & $\begin{array}{c}\text { Tahanan Jenis } \\
\text { Tanah }(\Omega \text {-meter) } \\
\rho=2 . \pi . a . R\end{array}$ \\
\hline \multirow{4}{*}{1} & \multirow{4}{*}{$\begin{array}{c}\text { Jumat, } 5 \text { Oktober } \\
2018\end{array}$} & 10.00 & 0,28 & 35,168 \\
\hline & & 12.00 & 0,30 & 37,68 \\
\hline & & 14.00 & 0,30 & 37,68 \\
\hline & & 16.00 & 0,28 & 35,168 \\
\hline \multirow{4}{*}{2} & \multirow{4}{*}{$\begin{array}{c}\text { Sabtu, } 6 \text { Oktober } \\
2018\end{array}$} & 10.00 & 0,29 & 36,424 \\
\hline & & 12.00 & 0,30 & 37,68 \\
\hline & & 14.00 & 0,30 & 37,68 \\
\hline & & 16.00 & 0,28 & 35,168 \\
\hline \multirow{4}{*}{3} & \multirow{4}{*}{$\begin{array}{c}\text { Minggu, } 7 \text { Oktober } \\
2018\end{array}$} & 10.00 & 0,29 & 36,424 \\
\hline & & 12.00 & 0,30 & 37,68 \\
\hline & & 14.00 & 0,30 & 37,68 \\
\hline & & 16.00 & 0,29 & 36,424 \\
\hline \multirow{4}{*}{4} & \multirow{4}{*}{$\begin{array}{c}\text { Jumat, } 12 \text { Oktober } \\
2018\end{array}$} & 10.00 & 0,28 & 35,168 \\
\hline & & 12.00 & 0,30 & 37,68 \\
\hline & & 14.00 & 0,30 & 37,68 \\
\hline & & 16.00 & 0,29 & 36,424 \\
\hline \multirow{4}{*}{5} & \multirow{4}{*}{$\begin{array}{c}\text { Sabtu, } 13 \text { Oktober } \\
2018\end{array}$} & 10.00 & 0,29 & 36,424 \\
\hline & & 12.00 & 0,30 & 37,68 \\
\hline & & 14.00 & 0,30 & 37,68 \\
\hline & & 16.00 & 0,28 & 35,168 \\
\hline & Tahanan Jenis Tan & b) Terbesa & aksimal) & $37,68 \Omega$-meter \\
\hline
\end{tabular}

Berdasarkan data hasil pengukuran pada tabel 1 didapat nilai tahanan jenis tanah $(\rho)$ terbesar yaitu 37,68 Ohm-meter.

\subsection{Perhitungan Sistem Pembumian \\ Pelat}

Tahanan pembumian untuk sistem pelat dengan kedalaman penanaman konduktor 1,5 meter :

$$
\begin{gathered}
R_{P l}=\frac{\rho}{4 \pi L}\left[1+1,84 \frac{b}{h}\right] \\
R_{P l}=\frac{37,68}{4 \times 3,14 \times 1}\left[1+1,84 \frac{1}{1,5}\right]=6,68 \mathrm{Ohm} \\
\text { Pada sistem pembumian pelat }
\end{gathered}
$$
dilakukan perubahan kedalaman penanaman konduktor (h) dari 1,5 meter 3 meter dan panjang pelat (L). Karena penanaman pelat kedalaman 1,5 meter dengan ukuran pelat $1 \mathrm{~m} \times 1 \mathrm{~m}$ didapatkan $\mathrm{R}_{\text {pelat }}=6,68 \mathrm{Ohm}$ belum memenuhi standar $\mathrm{R}_{\text {pelat }}<1$ Ohm, diperlukan memparalelkan pelat.

$$
\begin{aligned}
& R_{\text {total }}\left(\frac{1}{R_{t}}\right)=\frac{1}{6,68}+\frac{1}{6,68}+\frac{1}{6,68}+\cdots+\frac{1}{R_{7}} \\
& R_{\text {total }}\left(R_{t}\right)=\frac{6,68}{7}=0,95 \text { Ohm } \\
& N_{\text {Pelat }}=\frac{6,68}{0,95}=7 \text { lembar pelat } / \text { titik lokasi }
\end{aligned}
$$

Setelah memparalel pelat dengan merubah - ubah kedalaman dari 1,5 meter - 3 meter dan panjang pelat (L) maka didapatkan nilai tahanan pembumian yang paling minimum sebesar $0,80 \mathrm{Ohm}$ adalah kedalaman penanaman 3 meter sebanyak 9 lembar pelat.

\subsection{Perhitungan Sistem Pembumian Mesh}

Sistem pembumian Mesh merupakan sistem pembumian Grid tanpa elektroda Rod.

1. Untuk $\mathrm{D}=3$ meter ; $L_{c}=42$ meter dengan $h=1,5$ meter :

$$
\begin{aligned}
& R_{m}=\rho\left[\frac{1}{L_{c}}+\frac{1}{\sqrt{20 A}}\left(1+\frac{1}{1+h \sqrt{\frac{20}{A}}}\right)\right] \\
& R_{m}=37,68\left[\frac{1}{42}+\frac{1}{\sqrt{20 x 54}}\left(1+\frac{1}{1+1,5 \sqrt{\frac{20}{54}}}\right)\right] \\
& R_{m}=0,3063 \text { Ohm }
\end{aligned}
$$

2. Untuk $\mathrm{D}=4,5$ meter ; $L_{c}=36$ meter dengan $h=1,5$ meter :

$$
R_{m}=\rho\left[\frac{1}{L_{c}}+\frac{1}{\sqrt{20 A}}\left(1+\frac{1}{1+h \sqrt{\frac{20}{A}}}\right)\right]
$$




$$
\begin{aligned}
& R_{m}=37,68\left[\frac{1}{36}+\frac{1}{\sqrt{20 x 54}}\left(1+\frac{1}{1+1,5 \sqrt{\frac{20}{54}}}\right)\right] \\
& R_{m}=0,3293 \text { Ohm }
\end{aligned}
$$

Pada sistem pembumian mesh, setelah melakukan perhitungan dengan merubah - ubah kedalaman penanaman konduktor (h) dari 1,5 meter - 3 meter, didapatkan nilai tahanan pembumian yang paling minimum sebesar 0,2602 Ohm untuk $D=3$ meter dan 0,2797 Ohm untuk $D=4,5$ meter.

\subsection{Perhitungan Sistem Pembumian Grid - Rod}

Sistem pembumian Grid-Rod merupakan penggabungan dari dua jenis sistem pembumian yaitu Mesh dan Rod.

1. Untuk $\mathrm{D}=3$ meter ; $L_{c}=42$ meter dengan $\mathrm{h}=1,5$ meter :

$$
\begin{aligned}
R_{G} & =\frac{R_{1} R_{2}-R_{m}{ }^{2}}{R_{1}+R_{2}-2 R_{m}} \text { Ohm } \\
R_{G} & =\frac{(0,5795 \times 0,6780)-0,07134^{2}}{(0,5795+0,6780)-(2 \times 0,0713)} \\
R_{G} & =0,34780 \mathrm{hm}
\end{aligned}
$$

2. Untuk $\mathrm{D}=4,5$ meter ; $L_{c}=36$ meter dengan $\mathrm{h}=1,5$ meter

$$
\begin{aligned}
R_{G} & =\frac{R_{1} R_{2}-R_{m}{ }^{2}}{R_{1}+R_{2}-2 R_{m}} \text { Ohm } \\
R_{G} & =\frac{(0,5975 \times 0,8136)-0,0559^{2}}{(0,5975+0,8136)-(2 \times 0,0559)} \\
R_{G} & =0,37180 \mathrm{hm}
\end{aligned}
$$

Pada sistem pembumian Grid-Rod dilakukan perubahan ukuran diameter $(b)$ dan total panjang elektroda rod $\left(L_{r}\right)$ terhadap nilai tahanan pembumian GridRod yang akan digunakan. Ukuran diameter elektroda rod yang digunakan adalah diameter yang ada dipasaran yaitu sebesar $1,2 \mathrm{~cm}, 1,5 \mathrm{~cm}, 2 \mathrm{~cm}$ dan $2,5 \mathrm{~cm}$. Maka akan didapatkan nilai sistem pembumian yang paling minimum sebesar $0,2561 \mathrm{Ohm}$ untuk $\mathrm{D}=3$ meter dan 0,2618 Ohm untuk $D=4,5$ meter.

\subsection{Kriteria Tegangan Sentuh yang Diizinkan}

Kriteria tegangan sentuh untuk berat badan petugas $50 \mathrm{~kg}$ dengan waktu 1 detik:

$$
\begin{gathered}
E_{s 50}=\left[1000+1,5 \times C_{s} \times \rho_{s}\right] \frac{0,116}{\sqrt{t_{s}}} \\
E_{s 50}=[1000+1,5 \times 0,644 \times 3000] \frac{0,116}{\sqrt{1}}=452,44 \text { Volt }
\end{gathered}
$$

Kriteria tegangan sentuh untuk berat badan petugas $70 \mathrm{~kg}$ dengan waktu 1 detik:

$$
E_{s 70}=\left[1000+1,5 \times C_{s} \times \rho_{s}\right] \frac{0,157}{\sqrt{t_{s}}}
$$

$E_{S 70}=[1000+1,5 \times 0,644 \times 3000] \frac{0,157}{\sqrt{1}}=612,35$ Volt

Hasil kriteria tegangan sentuh yang diizinkan untuk waktu 0,1 sampai 3 detik untuk berat badan petugas $50 \mathrm{~kg}$ dan $70 \mathrm{~kg}$ seperti tabel 2 berikut :

Tabel 2. Hasil Perhitungan Kriteria Tegangan Sentuh

\begin{tabular}{|c|c|c|c|c|c|}
\hline No & $\begin{array}{c}\text { Lama } \\
\text { Gangguan } \\
\text { t (detik) }\end{array}$ & $\sqrt{\boldsymbol{t}}$ & $\begin{array}{c}\text { Tegangan } \\
\text { Sentuh } \\
\text { (Volt) } \\
\text { (IEEE std } \\
\mathbf{8 0 - 2 0 0 0 )}\end{array}$ & $\begin{array}{c}\text { Perhitungan } \\
\text { Tegangan } \\
\text { Sentuh 50 Kg } \\
\text { (Volt) }\end{array}$ & $\begin{array}{c}\text { Perhitungan } \\
\text { Tegangan } \\
\text { Sentuh 70 Kg } \\
\text { (Volt) }\end{array}$ \\
\hline 1 & 0,1 & 0,3162 & 1980 & 1430,74 & 1936,43 \\
\hline 2 & 0,2 & 0,4472 & 1400 & 1011,68 & 1369,26 \\
\hline 3 & 0,3 & 0,5477 & 1140 & 826,03 & 1118,00 \\
\hline 4 & 0,4 & 0,6324 & 990 & 715,37 & 968,21 \\
\hline 5 & 0,5 & 0,7071 & 890 & 639,84 & 866,00 \\
\hline 6 & 1,0 & 1 & 626 & 452,44 & 612,35 \\
\hline 7 & 2,0 & 1,4142 & 443 & 319,92 & 433 \\
\hline 8 & 3,0 & 1,7320 & 362 & 261,21 & 353,54 \\
\hline
\end{tabular}

\subsection{Kriteria Tegangan Langkah yang Diizinkan}

Kriteria tegangan langkah untuk berat badan petugas $50 \mathrm{~kg}$ dengan waktu 1 detik:

$$
\begin{gathered}
E_{l 50}=\left[1000+6 \times C_{s} \times \rho_{s}\right] \frac{0,116}{\sqrt{t_{s}}} \\
E_{l 50}=[1000+6 \times 0,644 \times 3000] \frac{0,116}{\sqrt{1}}=1461,76 \text { Volt }
\end{gathered}
$$

Kriteria tegangan langkah untuk berat badan petugas $70 \mathrm{~kg}$ dengan waktu 1 detik:

$$
E_{l 70}=\left[1000+6 x C_{s} x \rho_{s}\right] \frac{0,157}{\sqrt{t_{s}}}
$$

$E_{l 70}=[1000+6 \times 0,644 \times 3000] \frac{0,157}{\sqrt{1}}=1461,76$ Volt

Hasil kriteria tegangan langkah yang diizinkan untuk waktu 0,1 sampai 3 detik untuk berat badan petugas $50 \mathrm{~kg}$ dan $70 \mathrm{~kg}$ seperti tabel 3 berikut :

Tabel 3. Hasil Perhitungan Kriteria Tegangan Langkah

\begin{tabular}{|c|c|c|c|c|c|}
\hline No & $\begin{array}{c}\text { Lama } \\
\text { Gangguan } \\
\text { t (detik) }\end{array}$ & $\sqrt{\boldsymbol{t}}$ & $\begin{array}{c}\text { Tegangan } \\
\text { langkah } \\
\text { (Volt) } \\
\text { (IEEE std } \\
\mathbf{8 0 - 2 0 0 0 )}\end{array}$ & $\begin{array}{c}\text { Perhitungan } \\
\text { Tegangan } \\
\text { Langkah 50 Kg } \\
\text { (Volt) }\end{array}$ & $\begin{array}{c}\text { Perhitungan } \\
\text { Tegangan } \\
\text { Langkah 70 Kg } \\
\text { (Volt) }\end{array}$ \\
\hline 1 & 0,1 & 0,3162 & 7000 & 4622,49 & 6256,30 \\
\hline 2 & 0,2 & 0,4472 & 4950 & 3268,59 & 4423,87 \\
\hline 3 & 0,3 & 0,5477 & 4040 & 2668,79 & 3612,08 \\
\hline 4 & 0,4 & 0,6324 & 3500 & 2311,24 & 3128,15 \\
\hline 5 & 0,5 & 0,7071 & 3140 & 2067,24 & 2797,90 \\
\hline 6 & 1,0 & 1 & 2216 & 1461,76 & 1978,41 \\
\hline 7 & 2,0 & 1,4142 & 1560 & 1033,62 & 1398,95 \\
\hline 8 & 3,0 & 1,7320 & 1280 & 843,94 & 1142,24 \\
\hline
\end{tabular}




\subsection{Tegangan Mesh}

Tegangan Mesh dapat dihitung sebagai berikut.

1. Untuk $D=3$ meter.

a. Pada sistem pembumian mesh maka $\left(E_{m}\right)$ dapat dihitung sebagai berikut:

$$
E_{m}=\frac{\rho I_{G} K_{m} K_{i}}{L_{c}+L_{R}}
$$

$E_{m}=\frac{37,68 \times 7062,29 \times 0,0634 \times 1,23}{42+0}=497,22$ Volt

b. Pada sistem pembumian grid rod maka $\left(E_{m}\right)$ dapat dihitung sebagai berikut:

$$
\begin{gathered}
E_{m}=\frac{\rho I_{G} K_{m} K_{i}}{L_{c}+L_{R}} \\
E_{m}=\frac{37,68 \times 7062,29 \times 0,0634 \times 1,08}{42+35}=257,33 \text { Volt }
\end{gathered}
$$

Pada sistem pembumian Mesh dengan merubah kedalaman penanaman konduktor (h) dari 1,5 meter - 3 meter didapatkan nilai $E_{m}>E_{s 50}$ yang paling minimum yaitu sebesar 461,76 Volt $>452,44$ Volt, artinya sistem pembumian Mesh belum memenuhi kriteria tegangan sentuh yang diizinkan. Sedangkan, pada sistem pembumian grid rod dengan merubah diameter (b) dan panjang elektroda rod $\left(L_{r}\right)$ didapatkan nilai $E_{m}<E_{s 50}$ yang paling minimum yaitu sebesar 196,94 Volt < 452,44 Volt dengan kedalaman penanaman konduktor 3 meter dari atas permukaan tanah dan panjang elekroda rod 5 meter, artinya sistem pembumian grid rod sudah memenuhi kriteria tegangan sentuh yang diizinkan.

2. Untuk $D=4,5$ meter.

a. Pada sistem pembumian mesh maka $\left(E_{m}\right)$ dapat dihitung sebagai berikut:

$$
E_{m}=\frac{\rho I_{G} K_{m} K_{i}}{L_{c}+L_{R}}
$$

$E_{m}=\frac{37,68 \times 7062,29 \times 0,0627 \times 1,088}{36+0}=491,22$ Volt

b. Pada sistem pembumian grid rod maka $\left(E_{m}\right)$ dapat dihitung sebagai berikut:

$$
\begin{gathered}
E_{m}=\frac{\rho I_{G} K_{m} K_{i}}{L_{c}+L_{R}} \\
E_{m}=\frac{37,68 \times 7062,29 \times 0,0627 \times 1,088}{36+35}=331,4081 \text { Volt }
\end{gathered}
$$

Pada sistem pembumian Mesh dengan merubah kedalaman penanaman konduktor (h) dari 1,5 meter - 3 meter didapatkan nilai $E_{m}>E_{s 50}$ yang paling minimum yaitu sebesar 455,95 Volt > 452,44 Volt artinya sistem pembumian Mesh belum memenuhi kriteria tegangan sentuh yang diizinkan. Sedangkan, pada sistem pembumian grid rod dengan merubah diameter (b) dan panjang elektroda rod $\left(L_{r}\right)$ didapatkan nilai $E_{m}<E_{s 50}$ yang paling minimum yaitu sebesar 170,23 Volt $<452,44$ Volt dengan kedalaman penanaman konduktor 3 meter dari atas permukaan tanah dan panjang elekroda rod 5 meter, artinya sistem pembumian grid rod sudah memenuhi kriteria tegangan sentuh yang diizinkan.

\subsection{Tegangan Langkah}

Tegangan Langkah dapat dihitung sebagai berikut.

1. Untuk D = 3 meter.

a. Pada sistem pembumian mesh maka $\left(E_{l m}\right)$ dapat dihitung sebagai berikut:

$$
E_{l m}=\frac{\rho I_{G} K_{s} K_{i}}{0,75 x L_{c}+0,85 x L_{R}}
$$

$E_{l m}=\frac{37,68 \times 7062,29 \times 0,2123 \times 1,23}{0,75 \times 42+0,85 \times 0}=1420,52$ Volt

b. Pada sistem pembumian grid rod maka $\left(E_{l m}\right)$ dapat dihitung sebagai berikut:

$$
\begin{gathered}
E_{l m}=\frac{\rho I_{G} K_{s} K_{i}}{0,75 \times L_{c}+0,85 \times L_{R}} \\
E_{l m}=\frac{37,68 \times 7062,29 \times 0,2123 \times 1,23}{0,75 \times 42+0,85 \times 35}=1297,94 \text { Volt }
\end{gathered}
$$

Pada sistem pembumian Mesh dengan merubah kedalaman penanaman konduktor (h) dari 1,5 meter - 3 meter didapatkan nilai $E l_{m}<E_{l 50}$ yang paling minimum yaitu sebesar 1065,39 Volt < 1461,76 Volt. Sedangkan, pada sistem pembumian grid rod dengan merubah diameter (b) dan panjang elektroda rod $\left(L_{r}\right)$ nilai $E_{l m}<E_{l 50}$ dengan nilai tegangan langkah yang paling minimum sebesar 938,74 Volt < 1461,76 Volt dengan kedalaman penanaman konduktor 3 meter dari atas permukaan tanah dan panjang elekroda rod 5 meter. Maka, sistem pembumian mesh dan grid rod sudah memenuhi kriteria tegangan langkah yang diizinkan.

2. Untuk $\mathrm{D}=3$ meter.

a. Pada sistem pembumian mesh maka $\left(E_{l m}\right)$ dapat dihitung sebagai berikut:

$$
\begin{gathered}
E_{l m}=\frac{\rho I_{G} K_{S} K_{i}}{0,75 \times L_{c}+0,85 \times L_{R}} \\
E_{l m}=\frac{37,68 \times 7062,29 \times 0,083 \times 1,08}{0,75 \times 42+0,85 \times 0}=1057,02 \text { Volt }
\end{gathered}
$$

b. Pada sistem pembumian grid rod maka $\left(E_{l m}\right)$ dapat dihitung sebagai berikut:

$$
\begin{gathered}
E_{l m}=\frac{\rho I_{G} K_{s} K_{i}}{0,75 \times L_{c}+0,85 \times L_{R}} \\
E_{l m}=\frac{37,68 \times 7062,29 \times 0,083 \times 1,08}{0,75 \times 42+0,85 \times 35}=1188,69 \text { Volt }
\end{gathered}
$$

Pada sistem pembumian Mesh dengan merubah kedalaman penanaman konduktor (h) dari 1,5 meter - 3 meter didapatkan nilai $E l_{m}<E_{l 50}$ yang paling minimum yaitu sebesar 764,31 Volt < 1461,76 Volt. 
Sedangkan, pada sistem pembumian grid rod dengan merubah diameter $(b)$ dan panjang elektroda rod $\left(L_{r}\right)$ didapatkan nilai $E_{l m}<E_{l 50}$ dengan nilai tegangan langkah yang paling minimum sebesar 859,72 Volt < 1461,76 Volt, dengan kedalaman penanaman konduktor 3 meter dari atas permukaan tanah dan panjang elekroda rod 5 meter. Maka, sistem pembumian mesh dan grid rod sudah memenuhi kriteria tegangan langkah yang diizinkan.

\subsection{Rencana Anggaran Biaya (RAB) Sistem Pembumian \\ Jenis sistem pembumian yang akan} direncanakan di SS VVIP Bandar Udara Internasional I Gusti Ngurah Rai berdasarkan analisis akan RAB yang akan diperlukan untuk membangun sistem pembumian tersebut.

Tabel 4. Perbandingan RAB Sistem Pembumian di SS VVIP Bandar Udara Internasional I Gusti Ngurah Rai

\begin{tabular}{|c|c|c|c|}
\hline No & $\begin{array}{l}\text { Jenis Sistem } \\
\text { Pembumian }\end{array}$ & $\begin{array}{c}\text { Biaya Sistem } \\
\text { Pembumian } \\
\text { (Optimal) }\end{array}$ & Keterangan \\
\hline 1 & Pelat & 44.001 .000 - & $\begin{array}{l}\text { 1. Ukuran pelat } 1 \mathrm{~m} \times 2 \mathrm{~m} \\
\text { 2. Jumlah Pelat } 9 \text { Lembar Pelat } \\
\text { 3. Kedalaman Penanaman } 2 \text { Meter }\end{array}$ \\
\hline \multirow{2}{*}{2} & $\begin{array}{c}\text { Mesh } \mathrm{D}=3 \\
\text { Meter }\end{array}$ & $5.376 .000,-$ & $\begin{array}{l}\text { 1. Jarak Antar Konduktor }(\mathrm{D}=3 \mathrm{~m}) \\
\text { 2. Panjang Konduktor } 42 \text { meter } \\
\text { 3. Kedalaman Penanaman } 1,5 \text { Meter }\end{array}$ \\
\hline & $\begin{array}{c}\text { Mesh } \mathrm{D}=4,5 \\
\text { Meter }\end{array}$ & $4.608 .000,-$ & $\begin{array}{l}\text { 1. Jarak Antar Konduktor }(\mathrm{D}=4,5 \mathrm{~m}) \\
\text { 2. Panjang Konduktor } 36 \text { meter } \\
\text { 3. Kedalaman Penanaman } 1,5 \text { Meter }\end{array}$ \\
\hline \multirow[b]{2}{*}{3} & $\begin{array}{l}\text { Grid-Rod D } \\
=3 \text { Meter }\end{array}$ & $11.585 .000,-$ & $\begin{array}{l}\text { 1. Jarak Antar Konduktor }(\mathrm{D}=3 \mathrm{~m}) \\
\text { 2. Panjang Konduktor } 42 \mathrm{~meter} \\
\text { 3. Ukuran Rod }(0,012,3,5 \mathrm{~meter}) \\
\text { 4. Kedalaman Penanaman } 1,5 \mathrm{Meter}\end{array}$ \\
\hline & $\begin{array}{l}\text { Grid-Rod D } \\
=4,5 \text { Meter }\end{array}$ & $7.712 .500_{s}-$ & $\begin{array}{l}\text { 1. Jarak Antar Konduktor }(\mathrm{D}=4,5 \mathrm{~m}) \\
\text { 2. Panjang Konduktor } 36 \mathrm{~meter} \\
\text { 3. Ukuran Rod }(0,012,3,5 \mathrm{~meter}) \\
\text { 4. Kedalaman Penanaman } 1,5 \text { Meter }\end{array}$ \\
\hline
\end{tabular}

\subsection{Pemilihan Sistem Pembumian Berdasarkan Hasil Perhitungan}

Berdasarkan tabel 5, sistem pembumian yang paling aman ditunjukkan pada sistem pembumian Grid-Rod $D=4,5$ meter.

Tabel 5. Pemilihan Sistem Pembumian di SS VVIP Bandar Udara Internasional I Gusti Ngurah Rai

\begin{tabular}{|c|c|c|c|c|c|c|}
\hline No & $\begin{array}{c}\text { Jenis Sistem } \\
\text { Pembumian }\end{array}$ & $\begin{array}{c}\text { Tahanan } \\
\text { Pembumian } \\
(\text { Ohm })\end{array}$ & $\begin{array}{c}\text { Biaya Sistem } \\
\text { Pembumian } \\
\text { (Optimal) }\end{array}$ & Em & Elm & Keterangan \\
\hline 1 & Pelat & 0,96 & $44.001 .000,-$ & - & - & - \\
\hline \multirow{2}{*}{2} & $\begin{array}{c}\text { Mesh D }=3 \\
\text { Meter }\end{array}$ & 0,3063 & $5.376 .000,-$ & TM & M & Tidak Aman \\
\cline { 2 - 7 } & $\begin{array}{c}\text { Mesh D }=4,5 \\
\text { Meter }\end{array}$ & 0,3293 & $4.608 .000,-$ & TM & M & Tidak Aman \\
\hline \multirow{2}{*}{3} & $\begin{array}{c}\text { Grid-Rod D } \\
=3 \text { Meter }\end{array}$ & 0,3478 & $11.585 .000,-$ & M & M & Aman \\
\cline { 2 - 7 } & $\begin{array}{c}\text { Grid-Rod D } \\
=4,5 \text { Meter }\end{array}$ & 0,3718 & $7.712 .500,-$ & M & M & Aman \\
\hline
\end{tabular}

Keterangan :

1. (M) Memenuhi Standar (< Es 50) dan (< El 50)

2. (TM) Tidak Memenuhi Standar ( $>$ Es 50)(< El 50) dan (< Es 50)(> El 50)

\section{SIMPULAN}

Berdasarkan lokasi perencanaan pembangunan SS VVIP Bandar Udara Internasional I Gusti Ngurah Rai berada pada jenis tanah berpasir dengan nilai tahanan jenis tanah ( $\rho$ tanah) sebesar 37,68 Ohm - meter sehingga dari hasil analisis didapatkan sistem pembumian gridrod, dengan jarak antar konduktor grid $=4,5$ meter dan jumlah rod $=5$ dengan nilai tahanan pembumian $0,3718 \mathrm{Ohm}$, nilai tegangan sentuh 223,51 Volt, nilai tegangan langkah 1188,69 Volt dan Rencana Anggaran Biaya (RAB) dari hasil perhitungan adalah sebesar Rp 7.712.500.

\section{DAFTAR PUSTAKA}

[1] Hutauruk, TS. 1987. Pengetanahan Netral Sistem Tenaga dan Pengetanahan Peralatan. Jakarta : Erlangga.

[2] Dewi, N.A. 2013. " Optimalisasi Rancangan Sistem Pentanahan GridRod Pada Gardu Induk PLTP Ulubelu" (Tugas Akhir). Jakarta : Universitas Indonesia.

[3] IEEE Std 80 (2000). IEEE Guide for Safety in AC Substation Grounding, IEEE Society, New York.

[4] Janardana, IGN. 2005. Perbedaan Penambahan Garam dengan Penambahan Bentonit Terhadap Nilai Tahanan Pentanahan pada Sistem Pentanahan. Jurnal Teknologi Elektro. 4(1). 24-28.

[5] Sumardjati, P., dkk. 2008. Teknik Pemanfaatan Tenaga Listrik (Jilid 1). Jakarta : Departemen Pendidikan Nasional.

[6] Kantona, E. 2016. "Perencanaan Pemasangan Grounding Penangkal Petir pada Bangunan CF Silo di Proyek Indarung VI PT. Semen Padang" (Tugas Akhir). Padang : Politeknik Negeri Padang.

[7] Kusuma, M.A. 2013. "Studi Analisis Perencanaan Sistem Pentanahan Gardu Induk (GI) Bandara Ngurah Rai" (Tugas Akhir). Bali : Universitas Udayana.

[8] Kamal, J., Abduh, S. 2018. Perancangan Sistem Pentanahan Gas Insulated Switchgear (GIS) $150 \mathrm{kV}$ Pulogadung dengan Finite Element Method. Jurnal IImiah Teknik Elektro Universitas Tri Sakti. 15(2). 187- 200. 